\title{
Mitral repair in children with connective tissue disorders: On the edge, over the edge, or edge-to-edge?
}

\author{
Edward Buratto, MBBS, Xin Tao Ye, BBiomed, and Igor E. Konstantinov, MD, PhD, FRACS
}

\footnotetext{
From the Department of Cardiac Surgery, The Royal Children's Hospital, Melbourne; Department of Paediatrics, The University of Melbourne; and Murdoch Children's Research Institute, Melbourne, Australia. Disclosures: Authors have nothing to disclose with regard to commercial support.

Received for publication Sept 28, 2016; revisions received Sept 28, 2016; accepted for publication Sept 28, 2016; available ahead of print Nov 17, 2016.

Address for reprints: Igor E. Konstantinov, MD, PhD, FRACS, Royal Children's Hospital, Flemington Rd, Parkville, VIC 3029, Australia (E-mail: igor.konstantinov@rch.org.au).

J Thorac Cardiovasc Surg 2017;153:404-5

$0022-5223 / \$ 36.00$

Crown Copyright (c) 2016 Published by Elsevier Inc. on behalf of The American Association for Thoracic Surgery http://dx.doi.org/10.1016/j.jtcvs.2016.09.066
}

Mitral valve repair in patients with connective tissue disorders (CTDs) is challenging. The earlier in life that a repair has to be performed, the more difficult it is, because CTD that manifests in childhood represents the most severe end of the disease spectrum. ${ }^{1}$ Whereas in adults with CTD mitral valve repair can be achieved with similar outcomes to those with myxomatous mitral valve disease, ${ }^{2}$ the outcomes of mitral valve repair in children with CTD remain uncertain. ${ }^{1}$ The literature on the topic is sparse, with only a few small series, which report high rates of valve replacement. ${ }^{3,4}$

Children with CTD tend to have complex mitral valve pathology with progressive annular dilatation, thickening and nodularity of the leaflets, elongation, and rupture of multiple chordae, which results in bileaflet prolapse with characteristic leaflet redundancy. ${ }^{3}$ The complex repair is often on the edge of surgical ability and, if it fails, may push these fragile children over the edge, resulting in irretrievable deterioration. Although mitral replacement is an option in the face of such a challenging repair, survival after mitral replacement in young children is much poorer than survival after successful repair. ${ }^{5,6}$ Thus, a durable and simple technique for mitral repair in patients with CTD is of paramount importance. An ideal repair must achieve both stabilization of the mitral annulus and secure coaptation of the leaflets. Stabilization of the leaflet edges is particularly difficult, because of the unpredictable and progressive elongation and rupture of the chordae that may occur in any, or all, segments. Because of the unpredictable nature of chordal elongation and rupture, one would have to perform a complex total chordal augmentation ${ }^{7}$ or a simpler edge-to-edge approximation-the Alfieri stitch. ${ }^{8}$

The edge-to-edge technique was developed as a simplified method for the treatment of complex anterior and bileaflet mitral valve disease. ${ }^{8}$ Substantial experience from the group of Alfieri and colleagues ${ }^{8}$ has demonstrated that it is effective and provides durable long-term results in adults. An important article by Vricella and colleagues ${ }^{9}$ published in the current issue of the Journal describes excellent mid-term results

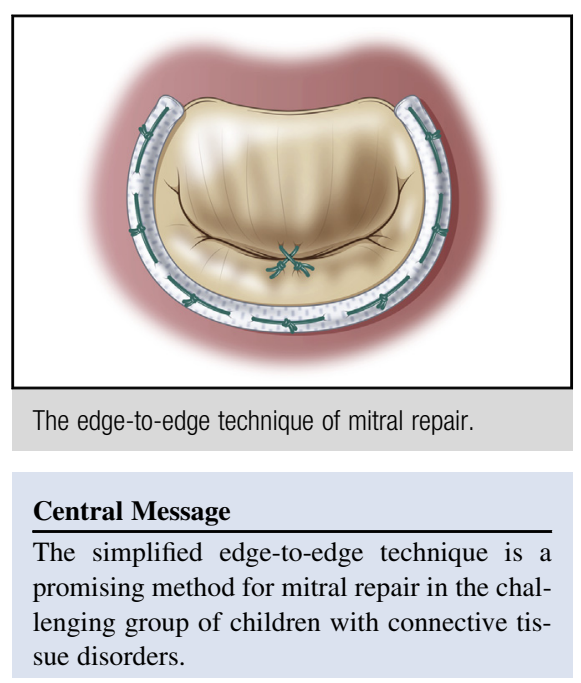

See Article page 399

of mitral valve repair using the edge-to-edge approximation technique in children with CTD. In a series of 18 patients with CTDs, the authors performed mitral repair using the edge-to-edge technique combined with annuloplasty using an adult-size ring. At a median follow up of 1.7 years, $94 \%$ of patients had mild mitral regurgitation or less, and there had been no reoperations on the mitral valve. Furthermore, there was significant regression of left ventricular end diastolic diameter observed during the study period. This simplified repair technique resulted in a short mean cross-clamp time, which is important considering many patients also will require concomitant aortic root surgery. Although the mid-term results are excellent, it remains to be seen whether this technique will provide durable longterm repair, given the progressive nature of CTD.

A particular challenge in young children with mitral regurgitation is achieving stabilization of the mitral annulus while allowing for somatic growth. In most children, severe dilatation of the mitral annulus permits implantation of adult-size annuloplasty ring (Figure 1, A), as demonstrated by Vricella and colleagues. ${ }^{9}$ In small children, when adultsize rings cannot be accommodated, annular stabilization can be achieved with a polytetrafluoroethylene band (Gore-Tex, Inc, Flagstaff, Ariz) divided into 2 or more segments to permit subsequent growth (Figure 1,B). Arguably, interconnecting the segments of the strip with absorbable suture may provide additional reinforcement and yet allow subsequent growth. ${ }^{6}$ 

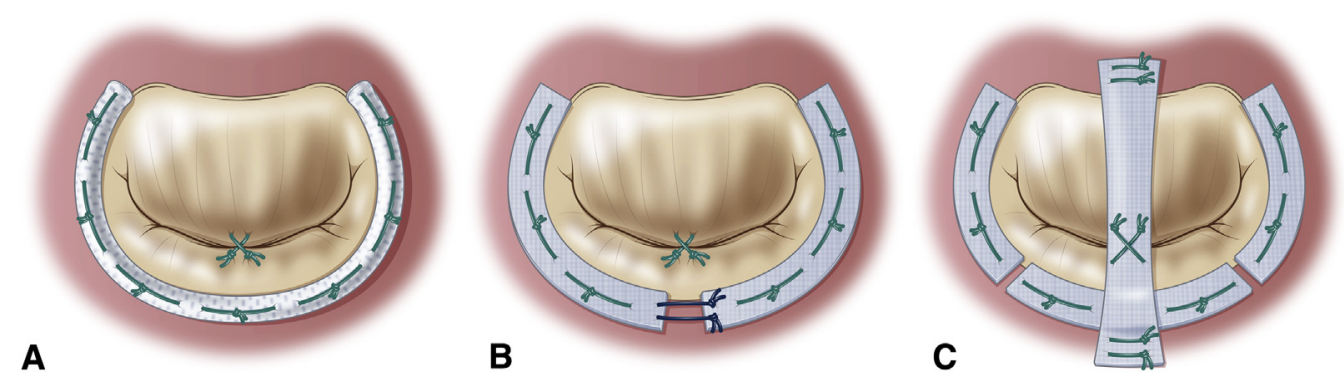

FIGURE 1. Edge-to-edge technique for mitral valve repair with (A) adult-size annuloplasty ring, (B) Gore-Tex strip annuloplasty and interconnecting absorbable suture, and (C) Gore-Tex bridge reinforcement.

Hopefully, the described technique will provide durable, long-term secure coaptation of the leaflets. This is yet to be seen. It is possible that further reinforcement of edge-toedge approximation may be required to achieve long-term durability in these challenging patients. We recently have reinforced edge-to-edge repairs with Gore-Tex bridges in children with univentricular hearts. ${ }^{10,11}$ This additional reinforcement (Figure 1,C) could be helpful in children with CTD. It is unclear which of these techniques will provide the best balance of annular stabilization and growth potential. Time will tell whether such additional stabilization will be required or not.

At the present time, we can say with certainty that edgeto-edge repair is here to stay. The technique described by Vricella and colleagues ${ }^{9}$ is an important and brave step forward and must be in the armamentarium of every congenital heart surgeon.

\section{References}

1. Gillinov AM, Zehr KJ, Redmond JM, Gott VL, Deitz HC, Reitz BA, et al. Cardiac operations in children with Marfan's syndrome: indications and results. Ann Thorac Surg. 1997;64:1140-4.
2. Helder MR, Schaff HV, Dearani JA, Li Z, Stulak JM, Suri RM, et al. Management of mitral regurgitation in Marfan syndrome: outcomes of valve repair versus replacement and comparison with myxomatous mitral valve disease. J Thorac Cardiovasc Surg. 2014;148:1020-4.

3. Cameron DE. Mitral valve surgery in children with Marfan syndrome. Progr Pediatr Cardiol. 1996;5:205-10.

4. Kim ER, Kim WH, Choi ES, Cho S, Jang WS, Kim YJ. Surgical Management of mitral regurgitation in patients with Marfan syndrome during infancy and early childhood. Korean J Thorac Cardiovasc Surg. 2015;48:7-12.

5. Alsoufi B, Manlhiot C, McCrindle BW, Al-Halees Z, Sallehuddin A, Al-Oufi S, et al. Results after mitral valve replacement with mechanical prostheses in young children. J Thorac Cardiovasc Surg. 2010;139:1189-96.

6. Oppido G, Davies B, McMullan DM, Cochrane AD, Cheung MM, d'Udekem Y, et al. Surgical treatment of congenital mitral valve disease: midterm results of a repair-oriented policy. J Thorac Cardiovasc Surg. 2008;135:1313-20.

7. Konstantinov IE, Jalali H. Total chordal augmentation in a child with Marfan syndrome and severe mitral insufficiency. Tex Heart Inst J. 2007;34:423-4.

8. Alfieri O, Maisano F, De Bonis M, Stefano PL, Torracca L, Oppizzi M, et al. The double-orifice technique in mitral valve repair: a simple solution for complex problems. J Thorac Cardiovasc Surg. 2001;122:674-81.

9. Vricella LA, Ravekes WA, Arbustini E, Jaquiss RDB, Mavroudis C, Dietz HC, et al. Simplified mitral valve repair in pediatric patients with connective tissue disorders. J Thorac Cardiovasc Surg. 2017;153:399-403.

10. Sughimoto K, Konstantinov IE, Brizard CP, d'Udekem Y. Polytetrafluoroethylene bridge for atrioventricular valve repair in single-ventricle palliation. J Thorac Cardiovasc Surg. 2015;149:641-3.

11. Konstantinov IE, Sughimoto K, Brizard CP, d'Udekem Y. Single ventricle: repair of atrioventricular valve using the bridging technique. Multimed Man Cardiothorac Surg. 2015 Sep 16; 2015: http://dx.doi.org/10.1093/mmcts/mmv027. 